\title{
Bank Holding Companies' Accounting Versus Economic Hedging Activities in the SFAS 133 Framework
}

\author{
Veliota Drakopoulou \\ Forbes School of Business, Ashford University, United States
}

Copyright (C) 2015 Horizon Research Publishing All rights reserved.

\begin{abstract}
The goal of this research was to investigate the controversy surrounding the inability of Statement of Financial Accounting Standard No. 133 (SFAS 133), Accounting for Derivative Instruments and Hedging Activities to portray the economics of hedging. This research examined whether or not the possibility of increased volatility evolved from economic hedges that do not qualify for hedge accounting under SFAS 133 prompted Bank Holding Companies (BHCs) to adjust their corporate risk management strategy to one that is more accounting responsive. Based on the results of this research, BHCs' which increased the level of accounting hedges and decreased the level of economic hedges experienced a significant decrease in earnings volatility relative to pre-SFAS 133. The findings suggest that BHCs' ability to reduce earnings volatility and increase earnings smoothing to meet analysts' expectations after the 2008 amendment of SFAS 133 has an adverse impact on BHCs' continual use of economic hedges. Analysts and investors are recommended to evaluate further BHCs' risk strategies to gain a better representation of their risk paradigm with derivatives. This study extends prior research on corporate risk management activities of BHCs and contributes to social change by presenting new affirmation to investors of the influence of SFAS 133 economic hedges on earnings volatility.
\end{abstract}

Keywords Derivatives, Accounting for Derivatives and Hedging Activities, Economic Hedges, Fair Value Hedges, Cash Flow Hedges, SFAS 133, Corporate Risk Management, Earnings Volatility, Earnings Smoothing

\section{Introduction}

In 2008, the Financial Accounting Standards Board (FASB), in response to the explosive derivative activities growth fueled by the financial market innovations and the need to actively manage financial risk exposures inherent in the operations of large financial institutions, amended Statement of Financial Accounting Standard No. 133 (SFAS 133), Accounting for Derivative Instruments and Hedging
Activities with the intention to regulate the accounting for corporate hedging strategies with derivatives and minimize the information asymmetry recognized in the standard before amended. The amended standard is effective for financial statements filed with the Securities and Exchange Commission (SEC) after September of 2008 [4, para.1].

The controversy surrounding SFAS 133 has centered on its incapacity to represent hedging economic risks and risk management activities. The biggest challenge companies face when reporting derivatives on the balance sheet is how to handle the gains and losses originating from changes in derivatives' fair value, since fair value fluctuates periodically [10, 2003]. Hedge accounting reduces earnings volatility by minimizing the potential income statement effect of the risk that is being hedged, since it causes the derivative gains or losses to influence revenues in the period corresponding to the gain or loss consequential to the risk being hedged.

The alternative to hedge accounting that is applied to economic hedges that do not qualify for hedge accounting is to recognize fluctuations in the recorded fair value of derivative hedging instruments immediately in earnings, causing redundant volatility in earnings. Proponents of the standard presumed that the hedging activities addressed in SFAS 133 mitigated the economic risks hedged with derivatives. This view is supported by Guay[20] and Melumad, Weyns, and Ziv[29] who illustrated that the accounting method used influenced the manager's hedging decision under a certain definition of fair-value hedge accounting preserving the ultimate economic hedge.

On the contrary, Barnes [5] supported that the hedge accounting regulations conforming to SFAS 133 led to misrepresentation of economic hedges. Peterson and Thiagarajon[34] disputed that the different accounting treatment of economically identical transactions (economic hedges vs. SFAS 133 accounting hedges) forced companies to base their hedging decisions on the accounting treatment the hedges received. In the same spirit, Lins, Servaes, and Tamayo[28] studied the results of SFAS 133 on firms' corporate risk management activities and found that $40 \%$ of the surveyed firms had to alter their hedging strategies since they felt their ability to use economic hedges had been 
compromised. Kolbasovsky[27] identified firms that recently restated their financial statements as a result of the misclassification of economic hedges as accounting hedges and found that only $58 \%$ of these firms continued the use of economic hedges disregarding the increased earnings volatility resultant of the accelerated earnings recognition of the economic hedges.

Given that the purpose of hedging is to shield the financial statements from the effect of conflicting fluctuations in interest rates, foreign exchange rates, or credit rates according to Coughlan[10], it is alleged in the financial markets that companies exercising derivatives for hedging would reassess their risk management approach to one that is more accounting responsive to ensure that all hedges are highly effective to qualify for hedge accounting. Consistent with this view, DeMarzo and Duffie [12] confirmed that the ideal hedging strategy implemented by executives is determined by the accounting information presented to stockholders, clarifying firms' given emphasis on hedging accounting risks rather than economic risks.

This study extended the corporate risk management behavior of BHCs in the framework of SFAS 133 as amended in 2008. Although accounting for derivative instruments and hedging activities has been one of the most debated issues among academics and practitioners, no prior research provided evidence of how the corporate risk management behavior of BHCs depended upon the accounting and the underlying economics of hedging. The new paradigm for corporate risk management discussed reflects BHCs' undertaking to detain the economic benefits of hedging associated with Statement 133's differential treatment of the gains and losses of accounting vs. economic hedges. This research improved upon previous research by investigating BHCs' hedging activities to find possible differences in earnings volatility related to the timing of the amount of gains and losses recognized in income on derivative hedging instruments for accounting vs. economic hedges [14, para.17-35]. Prior accounting literature on SFAS 133 failed to measure the influence of economic hedges on earnings volatility and focused only on firms' incentives to reduce reported earnings volatility by measuring whether or not firms moderated the use of derivatives after the adoption of SFAS 133 and increased earnings smoothing through discretionary accruals (see Park[33]; Singh[39]; Zhang[44]; Zhou[46].

\section{Hypothesis Development}

\subsection{Hypothesis Development of BHCs Corporate Risk Management Philosophy in the SFAS 133 Framework}

The FASB, in the original pronouncements as amended for accounting for derivative instruments and hedging activities required that:
An entity should recognize all of its derivative instruments on the balance sheet as either assets or liabilities at fair value. The accounting for gains or losses resulted from changes in the fair value of a derivative depends on whether it has been designated and qualifies as part of a hedging relationship and, if so, on the reason for holding it. For a derivative designated as hedging the exposure to changes in the fair value of a recognized asset or liability, the gain or loss is recognized in earnings in the period of change together with the offsetting loss or gain on the hedged item attributable to the risk being hedged. The effect of that accounting is to reflect in earnings the extent to which the hedge is not effective in achieving offsetting changes in fair value. For a derivative not designated as a hedging instrument, the gain or loss is recognized in earnings in the period of change. [14, para.17-18, p.15]

In the banking industry, according to Park[33] there is an intense debate about whether or not recognizing the fluctuations in fair value of derivative hedging instruments that do not comply for hedge accounting immediately in earnings under SFAS 133 would increase reported earnings volatility, subsidizing both banks' competence to administer risk efficiently and sustain customers' demand for derivatives. Khan[26] prognosticated that under fair value accounting banks with bigger quotas of derivative assets and liabilities would be influenced more since they countenance the burden to discount their derivate assets prices in a bearing stock market to either prevent sale by others or breach capital adequacy ratios.

Banks' corporate risk valuation is significant, according to Clark, Desisle, and Doran[7], because of banks' important role as financial intermediaries. Clark et al.[7] concluded that banks' excessive exposure to foreign exchange, interest rates, and other risks not only causes banks and their customers' potential suffering, but causes capital markets to lose additional access to financing through decreased market liquidity.

Park[33] argued that SFAS 133 affected both banks' sales and corporate risk management policies for derivatives and hedging activities since banks participating in the derivatives markets function as both dealers and end users of derivatives. BHCs revenues from sales of derivatives would decrease if the demand for banks' derivative products decreased. BHCs' hedging policies could result in the implementation of fewer effective hedges if the perceived notion that the use of derivatives that do not comply for hedging designation might increase earnings volatility. Therefore, SFAS 133 would lead to banks' negative stock price reactions if investors conceive that the implementation of SFAS 133 might affect negatively banks' derivative sales and their ability to hedge using derivative instruments.

The problem stemming from the initiation of SFAS 133 is that the possibility of increased volatility evolved from economic hedges that do not comply for hedge accounting might have prompted some BHCs to adjust their corporate 
risk management strategies to be more accounting responsive to smooth earnings in order to avoid analysts' negative stock valuations. BHCs along with the reassessment of their corporate risk management strategy, must also address the implementation of 2008 SFAS 133, since the standard "placed the burden on management to design an appropriate effectiveness test, and measure the change in fair value or cash flows attributable to the risk being hedged" [14,p.129], thus advocating an opportunistic earnings management behavior.

The Board recognized that SFAS 133, although clarified and accommodated "hedge accounting for more types of derivatives and different views or risks" [14,para.242,p.108] acclaimed that the standard did not provide a distinctive approach for evaluating hedge effectiveness, imposing the responsibility to the management to originate the appropriate hedge-effectiveness tests while taking into consideration the risk management tactics of the corporation, the nature of the hedged risk, and the type of derivatives used as hedging instrument [14,para.361].

BHCs' design of effectiveness tests are determined by the concern of the additional earnings volatility, possibly evolved from economically effective hedges that do not qualify for hedge accounting. The possibility of additional volatility in the income statement has caused banks' apprehension of negative stock valuations, as supported by the theoretical findings of Suh[40], Thapa and Brown[41], Wang[43], and Park[33]. Specifically, Thapa and Brown[41] and Park[33] construed that negative stock price reaction to earnings announcements encourage the negative financial fallout of SFAS 133 and are indicative of investors' views that Standard 133 introduces volatility to reported earnings.

Suh[40] predicted that firms with a more transient investor base would decrease their hedging activities to a greater extent post SFAS 133 than firms with a more long-term investor base because transient investors are more concerned with the potential increase in short-term earnings volatility resulting from derivatives that do not comply for hedge accounting. In order to gain investors' appreciation through a higher price-earnings ratio for implementing an efficient corporate risk management strategy, companies should be able to inform their stockholders for their hedging strategies, according to McCormack[30], a Morgan Stanley equity researcher, who argued that SFAS 133 reduced the effectiveness of economic risk management practices of companies by making it impractical to hedge real economic risk exposures devoid of earning volatility.

Contributing to the corporate risk management literature, Suh[40] argued that the hedging disclosures of SFAS 133 did not provide a clear picture of whether companies' earnings volatility intensifications originated from speculative hedges or from economic hedges. Allayannis, Rountree, and Weston[1] documented that financial statement volatility is costly and directly affects a firm's value. In the same spirit, Trombey[42] attested that most financial institutions attempt to decrease earning volatility with hedging since negative earnings surprises signal an incompetent corporate risk management and are viewed negatively by investors and analysts. Wang[43] documented that, although bad and good earnings news (as measured by the square of standardized unexpected earnings [SUE] increased future return volatility, bad earnings news raised future volatility more than good earnings news did.

The expectation of added volatility in financial statements has instigated significant concern for many BHCs, as they fear it would vanguard lower firm valuations. Corman[9] stated that Fitch Ratings, in a 2004 study, found enormous inconsistencies in the corporate implementations of SFAS 133, which produced significant uncertainty for investors and rating agencies, while the restatements related to the implementation of hedge accounting for certain derivative transactions under SFAS 133 ascended greatly since 2003, from 514 to about 1,200 in 2005 .

Bank of America in 2006 restated its historical financial statements for the years 2001-2005 related to the accounting designation for certain derivative instruments under SFAS 133 because "a number of the transactions included in the restatement did not meet the strict requirements of the shortcut method of accounting under SFAS 133" [2, Note 1:Summary of Significant Accounting Principles,p.93]. Additionally, Davis[48] reported that SunTrust Banks Inc. adjusted their 2006 fourth quarter earnings to correct accounting errors related to certain derivatives transactions from 2003 to 2005, and two Alabama banking companies-Compass Bancshares Inc., and Colonial BancGroup Inc. - also restated earnings in 2006 because of SFAS 133.

\subsection{Mortgage Banking Risk Management and Accounting for Economic Hedges}

SFAS 133 as the primary directive for the accounting treatment of derivative instruments in the United States requires all entities to disclose information about the interest rate, foreign exchange rate, and credit risk exposures hedged with derivative instruments. Statement 133 constrains financial institutions to distinguish between derivative instruments designated as hedges used for corporate risk management purposes such as fair value hedges and cash flow hedges and derivative instruments used to hedge economic risks such as economic hedges [14, para.44]. Derivatives instruments used by BHCs and designated as economic hedges do not comply for hedge accounting under SFAS 133 and should be included in derivative assets or derivative liabilities.

Bank of America in its 2008 10-K stated that: Economic hedges used in mortgage banking to decrease the sensitivity of earnings to interest rate and market value fluctuations include: interest rate swaps that do not qualify for the shortcut method (used to open or close gaps identified by the Asset-Liability management (ALM) of banks), mortgage servicing rights (MSRs), interest rate lock commitments (IRLCs), first mortgage loans held-for- sale (LHFS), and credit derivatives. Changes in the fair value of derivatives 
that serve as asset and liability management (ALM) economic hedges, which do not qualify or were not designated as accounting hedges, should be recorded in other income (loss). Changes in the fair value of derivatives that serve as economic hedges of mortgage servicing rights (MSRs), interest rate lock commitments (IRLCs) and first mortgage loans held-for-sale (LHFS) should be recorded in mortgage banking income. Credit derivatives used by a bank do not qualify for hedge accounting under SFAS 133 despite being effective economic hedges and changes in the fair value of these derivatives should be included in other income (loss). [2, 10K, p.112]

\subsubsection{ALM Economic Hedges}

BHCs' utilize interest rate derivatives in their ALM portfolio to decrease earnings volatility resulting from adverse interest rate movements as part of their corporate risk management strategy to protect profitability and capital adequacy ratios. The gains and losses derived from BHCs interest rate derivative instruments are likely to offset increases or decreases of the net interest margin of variable-rate hedged assets and liabilities due to changes in market interest rates. Interest rate swap derivatives are utilized in BHCs ALM portfolio to manage exposures from fluctuations in interest rates. Interest rate swaps are used to hedge fixed- interest rates against floating- interest rates by providing an agreement between two parties to exchange a fixed payment for a floating payment linked to the LIBOR.

Interest rate swaps that transfer fixed interest rate debt to floating interest debt are fair value hedges and swaps that transfer floating interest rate debt to fixed interest rate debt are cash flow hedges [14, para.68-70]. Interest rate swaps are designated to hedge the gains and losses on the hedged item due to changes in benchmark interest rates such as the U.S. Treasury rates or the LIBOR. The benchmark interest rate concept was first presented in SFAS 138 as a substitute for the risk-free rate concept that the FASB originally used in Statement 133 [14, para.540]. The shortcut method can be used for both swap fair value hedges and cash flow hedges if the hedging relationship meets certain conditions simplifying swap accounting. Under the shortcut method of accounting if the fair value of an interest rate swap is zero at the inception of the hedging relationship then no- hedge ineffectiveness is assumed and the changes of the hedged item value offset the estimated changes in value of the swap in every period [14, para.114]. However, if the fair value of an interest rate swap is not zero at the inception of the hedging relationship then the interest rate swap does not comply for the shortcut method and it is considered an economic hedge instead [14, para.68(b)].

\subsubsection{IRLCs and LHFS Economic Hedges}

Interest rate lock commitments (IRLCs) are derivative loans that expire usually 60 days after the commitment day between a loan borrower and a lender mortgage bank under which the lender agrees to finance a residential loan on a fixed-rate, adjustable-rate or floating- rate basis, without taking into consideration market interest changes according to FDIC[16]. Under SFAS No. 149, "Amendment of Statement 133 on Derivative Instruments and Hedging Activities," derivative loan commitments associated with the commencing of mortgage loans held- for- sale (LHFS) are assumed to be derivatives and are reported on the balance sheet at fair value while their gains and losses are recognized in mortgage banking income [14, para.6(c) \& 10(i)]. Outstanding IRLCs expose BHCs to the risk that the underlying rate of the LHFS might decrease during the commitment period affecting the value of the loan. BHCs economically hedge the risk of prospective changes in the value of the loan by hedging the underlying rate of the mortgage loan with forward loan sales commitments, interest rate swaps and options. Bank of America[2]; Ryan[38].

\subsubsection{MSR Economic Hedges}

FASB Statement 122 Accounting for Mortgage Servicing Rights [15] defines mortgage servicing rights (MSRs) as the rights of a mortgage lender to service an existing mortgage through either the purchase or origination of the mortgage loan. MSRs are accounted for at fair value and the gains and losses due to changes in the fair value of those MSRs are recorded in mortgage banking income. Interest rate options and swaps, forward settlement contracts, and euro-dollar futures are used as economic hedges of MSRs to decrease the sensitivity of earnings due to market interest rate variations [2]. According to Hutchison[24] hedging the MSR derivative portfolio is economically speculative and potentially generates considerable cash flow volatility. At the same time MSR accounting causes sizable earnings volatility independent of the cash flow volatility determined by the valuation effects of interest rate shocks on MSRs and the accounting asymmetry of MSR-origination loans. The author proposed that banks may be forced to uneconomically hedge their mortgage banking loans positions if they the perceived accounting asymmetry on cumulative earnings persists for long periods.

\subsubsection{Credit Derivatives}

Banks enter credit derivatives mainly to economically hedge their credit exposures associated with loans and also to provide credit derivatives to clients who want to intensify or reduce credit-default exposures. Bedendoa and Brunella[6] presuming on the main hypothetical incentives for credit risk transfer (CRT) found that undercapitalized banks with high credit-risk loan portfolio management, cash-flow shortages, and asymmetric information constraints tend to utilize customary CRT provisions such as guaranteed loans and syndicated \& securitized financing, while large banks with satisfying capital adequacy ratios responded to adverse financial shocks by increasing the use of credit derivatives.

Based on Bank of Americas[2] financial statements, credit derivatives are contractual agreements that allow BHCs to generate or to lessen credit exposure linked to defaulting mortgage loans, foreclosing, liquidation or interest rate and foreign-exchange rate fluctuations. A BHC as the credit 
protection buyer mitigates customers' default- risk by entering into a credit protection agreement with a protection buyer. A BHC as the protection buyer pays the protection seller a recurring charge during the term of the credit derivative expecting to get compensated from the protection seller in case a customer defaults payments on a loan. Jun[47] detailed that model risk (derived from the complex models of credit derivatives, settlement risk (derived from the settlement of credit derivatives following a default), and counterparty credit risk was some of the imposed challenges faced by commercial banks in their attempt to administer the risk of their loan portfolio using credit derivatives.

\section{Hypothesis Development of BHCs Corporate Risk Management Philosophy in the SFAS 133 Framework}

In the existing accounting literature, there is a belief that some BHCs might have been prompted to adjust their corporate risk management strategy to one that is more accounting responsive to avoid increased earnings volatility with hedge accounting. SFAS 133 has compromised BHCs' capacity to economically hedge financial risks since they are forced to decide between using economic hedges that increase earnings volatility but efficiently handle economic risks or decrease earnings volatility using corporate risk management approaches that are economically ineffective or not practical. These concerns have been supported by the theoretical findings of Kolsasovsky[27], Lins, Servaes, and Tamayo[28], Revsine, Collins, and Johnson[37], Peterson and Thiagarajon[34], and DeMarzo et al.[12]. Characteristically, Lins et al.[28] stated that:

Firms that operate in an environment where contracts are more likely to be written on accounting data, and firms that attach more importance to the reduction of earnings volatility as a benefit of risk management are more affected and care more about obtaining hedge accounting. (p. 34)

Additionally, Green (2008) stated that Statement 133 does not permit special hedge accounting for all relationships that may be economic hedges. A BHC, in order to designate a hedging relationship for SFAS 133 hedge accounting purposes, must identify the hedged asset, liability, or transaction, but that designation might not necessarily correspond exactly with management's overall economic goals. The author concluded that BHCs would be reluctant to use economic hedges if the accounting income is going to be affected adversely, not by economic events, but by the accounting convention applied to hedges (not allowing hedge accounting).

The Financial Accounting Standards Committee of the American Accounting Association, in a comment letter (1999) to the Joint Working Group of Standard Setters (JWG), defended the idea that SFAS 133, by not allowing a hedge designation for economic hedges, causes financial statements to suffer from material economic earnings volatility due to the lack of a fair value measurement of hedged items. This view was supported by the theoretical findings of Lins et al.[28], who documented a considerable diminution in derivative instruments with a negative likelihood to comply for hedge accounting under SFAS 133 such as foreign exchange derivatives and nonlinear derivatives such as vanilla options and exotic derivatives.

According to the extant accounting literature, economic hedges used " in mortgage banking to reduce the sensitivity of earnings to interest rate and market value fluctuations" $[2$, p.112] cause increased volatility in earnings since they do not qualify for hedge accounting. Specifically, the accounting treatment of MSRs creates a serious earnings timing difference between the recognition of servicing rights losses and the income from mortgage origination that exposes even an economically (cash flow) hedged mortgage bank to serious earnings volatility. Hutchison[24] suggested that many economically hedge mortgage banks will have incentives to take uneconomic hedge positions against their servicing rights portfolios because that short-term earnings volatility induced by the asymmetric accounting treatment of the servicing and origination franchises is marked and persistent.

Additionally, if the fair value of an interest rate swap is not zero it does not qualify for the shortcut method. In this case, the change in the value of hedged item and the swap are calculated separately, and the difference between the two is charged to income creating earnings volatility, which can be significant if the swap is not well matched to the hedged item [14, para.114].

According to the Office of the Comptroller of the Currency [32] because no hedging forward loan sales commitments are assessed at fair value all through earnings when the fair value of the mortgage loans increase above their cost basis would cause increased volatility in reported earnings. The reported earnings volatility is resulting from realizing in income the amount of loss from changes in the fair value of the forward loan sales commitments without modifying the book value over the costs basis of the mortgage loans.

Therefore, to determine whether the possibility of increased volatility evolved from economic hedges that do not comply for hedge accounting under SFAS 133 prompted some BHCs to adjust their corporate risk management strategy to one that is more accounting responsive, the following research question was proposed:

Did BHCs hedge in the optimal economic way (thus recognizing the volatility in earnings originated from those hedges that did not comply for hedge accounting treatment), or did BHCs hedge in a limited fashion only where hedge accounting treatment could be attained (thus evading additional earnings volatility and decreasing just a limited amount of the economic risks)?

H10: There was no difference in the mean notional value 
of derivatives for SFAS133-compliant hedgers and SFAS133-accounting hedgers after the 2008 amendment of SFAS 133.

H1a: There was a difference in the mean notional value of derivatives for SFAS133-compliant hedgers and SFAS133-accounting hedgers after the 2008 amendment of SFAS 133.

\section{Research Design and Empirical Models}

\subsection{Measurement of Derivatives}

"The FASB decided to define derivative instruments based characteristics rather than simply referring to financial instruments commonly known to be derivatives.' Trombley[42, p.26]. The FASB wanted to make sure that as new derivatives are invented, Statement 133 would continue to apply to them as long as their characteristics are similar to those of currently available derivatives. Trombley[42]. Financial instruments have three characteristics according to the FASB's definition of derivatives, included in the scope the definition of SFAS 133 [14, para.6]. First, "derivatives should have one or more underlying prices or values and one or more notional amounts and/or contract payment provisions" (p. 8). Second, derivative contracts should require a zero invested capital to initiate or an invested capital that is lesser than comparable investment contracts with analogous expected responses to financial market changes. Third, derivatives should necessitate a cash payment settlement between the contract parties or settlement by delivery of an asset that can be easily converted into cash or is another derivative.

In the extant literature, the notional principal amounts of the overall derivatives positions (swaps, forwards, futures and options based on interest rates, exchange rates, and other underlying instruments) is used to measure derivatives as a proxy for hedging according to Bartram, Brown, and Conrad[4]; Gilkeson and Smith[17]; Hirtle[21]; Park[33]; Purnanandam[36]; Zhao and Moser[45]. The total notional amount of derivative instruments designated as economic hedges of MSRs, IRLCs, LHFSs, ALMs, and credit derivatives and the total notional amount of the derivatives instruments and other securities designated as fair value hedges and cash flow hedges were used as a measure of derivatives.

\subsection{Model for Testing BHC's Corporate Risk Management Behavior}

This research investigated the Corporate Risk Management Behavior of BHCs by testing whether or not BHCs exhibited a more accounting responsive risk management approach and hedged in a limited fashion only where hedge accounting treatment could be attained after the 2008 amendment of SFAS 133. Descriptive statistics were used to measure if there is a significant difference on the use of derivative instruments designated as accounting hedges and economic hedges by BHCs in 2008 (the year SFAS 133 was amended) and in 2009 (one year after the 2008 amendment of SFAS 133). Descriptive statistics provided information about (1) the total notional value of cash flow hedges, fair value hedges, and economic hedges of SFAS133-accounting hedgers and SFAS133-compliant hedgers, (2) the dependent and independent variables of both groups, and (3) the effects of derivative instruments on the income statement for both groups.

More specifically, t-tests were conducted to compare possible differences in the mean notional value of derivatives designated as cash flow hedges, fair value hedges, and economic hedges of the two groups of BHCs as reported in their 2008 and 2009 financial statements. Furthermore, to test research question one, Singh's[39] multivariate regression model was referenced. Using Singh's[39] modified regression model, the mean notional value of derivative instruments for SFAS133-accounting hedgers and SFAS133- compliant hedgers is regressed on their motivation to decrease earnings volatility and on regression control variables that proxy for the hedging incentives of these two groups of BHCs. These control variables proxied for financial distress, managerial risk aversion, underinvestment costs, information asymmetry, and the regulatory capital adequacy of BHCs based on prior literature on theoretical corporate risk management. A definition of the variables utilized in this research is presented in Appendix A.

Additionally, two dummy variables were incorporated in the regression equation to proxy for the period after the 2008 amendment of SFAS 133 (After) and to designate BHCs as accounting or compliant hedgers (HAT). The use of the two dummy variables helped evaluate the coefficient differentiations of the independent variables after the 2008 amendment of SFAS 133 relative to the coefficients before the 2008 amendment of SFAS 133 for both BHCs groups. After is a dummy variable coded as 1 for the post-2008 amendment of SFAS 133 and coded as 0 otherwise. HAT is a dummy variable coded as 1 when BHCs use both economic and accounting hedges and coded as 0 otherwise. Particularly, the multivariate regression took the following form:

Notionalit $=\beta 0+\beta 1$ EVolit $+\beta 2$ ESmoothit $+\beta 3$ ESmooth 1 it
$+\beta 4$ FINLEVit $+\beta 5$ CapAdeq1 it $+\beta 6$ UNDERCit +
$\beta$ IINFOASYit $+\beta 8$ MNGRiskit $+\beta 9$ IRLibor + eit

\subsection{Limitations}

Since Statement 133 became effective for financial statements registered with the SEC for fiscal years beginning after September 2008, only 1 year of data were available for BHCs derivatives and hedging activities after the 2008 amendment of SFAS 133. For this reason, the scope of this study was limited to the year Statement 133 was amended (2008) and 1 year after the standards' amendment (2009). 
This limitation might compromise the ability of this study to produce accurate results about whether or not BHCs adjusted their corporate risk management strategies to be more accounting responsive, in the case that BHCs felt they did not have sufficient time to review, comprehend, and execute the amended requirements of Statement 133 while finalizing all necessary computer-based information system conversions.

\section{Results of Tests of Hypothesis}

\subsection{Descriptive Statistics}

The primary data examined in this study are for U.S. BHCs in Peer 1 and Peer 2 Groups with total assets greater than $\$ 10$ and $\$ 3$ billion respectively. The list of the BHCs Peer Groups as of the third quarter of 2009 was obtained from the National Information Center of the Federal Reserve Board home page found at http://www.ffiec.gov/nicpubweb/content/BHCPRRPT/BHC PR Peer.htm. The focus of this study is on the largest financial institutions because BHCs in Peer 1 and Peer 2 Groups epitomize the derivative activities of the entire banking industry which helps avoid sample selection bias. According to the Comptroller of the Currency[32], in the United States the derivatives market is controlled by the five largest BHCs which represent $97 \%$ of the total financial industry's notional amount of derivatives. Additionally, the OCC [32] trusts that these financial institutions have the sophisticated tools and expertise needed to operate in the "highly specialized business of structuring, trading, and managing derivatives transactions" $[32$, p.1].

The data for the derivative instruments and hedging activities of the sampled BHCs were collected from their annual financial statements $(10 \mathrm{Ks})$ found in the Edgar Filing System of the SEC by using the open full reader search and keyword searches such as notional, cash flow hedges, fair value hedges, economic hedges, derivatives, and SFAS 133 from fiscal year 2008 to fiscal year 2009. In the BHCs official website under investor relations, data for the CEOs stock option-based compensation were retrieved from the BHCs proxy statements, while data on the number of analysts following the company were retrieved under analyst coverage.

Appendix B provides a listing of BHCs in Peer Groups 1 and 2 based on their reporting of derivatives designated as hedging instruments in compliance with SFAS 133 as of December 31, 2009. Of the entire target population of 167 BHCs, 62 BHCs used derivatives that qualified for hedge accounting, 76 BHCS used derivatives that did not qualify for hedge accounting, $23 \mathrm{BHCs}$ did not use any derivatives, 5 BHCs only used trading derivatives, and 3 BHCs used derivatives that complied with international financial reporting standards (IFRS). Specifically, 45 BHCs from Peer 1 Group and 17 BHCs from Peer 2 Group used derivatives that qualified for hedge accounting. In Peer 1, 20 BHCs were classified as SFAS133-compliant hedgers and 25 BHCs were classified as SFAS133-accounting hedgers. In Peer 2, four BHCs were classified as SFAS133- compliant hedgers and 13 BHCs were classified as SFAS133-accounting hedgers.

Table 1 provides descriptive statistics for the 2008 and 2009 total notional value of hedging instruments designated as accounting, cash flow, fair value, and economic hedges for SFAS133-compliant and SFAS-accounting hedgers to investigate whether or not BHCs increased their level of accounting hedges and decreased their level of economic hedges in response to the 2008 amendment of SFAS 133. For SFAS133-accounting hedgers results suggest that the 2009 notional value of cash flow hedges $(\mathrm{M}=1.05, \mathrm{SD}=2.46)$, fair value hedges $(\mathrm{M}=0.73, \mathrm{SD}=1.88)$, and accounting hedges $(\mathrm{M}=2.96, \mathrm{SD}=3.34)$ were significantly higher than the 2008 notional value of cash flow hedges $(\mathrm{M}=0.26, \mathrm{SD}=$ 2.68), fair value hedges $(\mathrm{M}=0.12, \mathrm{SD}=1.79)$, and accounting hedges $(\mathrm{M}=2.20, \mathrm{SD}=4.40)$. For SFAS133-compliant hedgers results suggest that for 2009 the notional value of fair value hedges $(\mathrm{M}=0.97, \mathrm{SD}=1.88)$ and accounting hedges $(\mathrm{M}=1.89, \mathrm{SD}=4.26)$ were significantly higher than the 2008 notional value of fair value hedges $(\mathrm{M}=$ $0.94, \mathrm{SD}=1.26)$ and accounting hedges $(\mathrm{M}=1.03, \mathrm{SD}=$ 2.33), while for 2009 the notional value of cash flow hedges $(\mathrm{M}=1.41, \mathrm{SD}=2.42)$ and economic hedges $(\mathrm{M}=1.79, \mathrm{SD}=$ $3.45)$ were significantly lower than the 2008 notional value of cash flow hedges $(\mathrm{M}=1.68, \mathrm{SD}=2.38)$ and economic hedges $(\mathrm{M}=1.95, \mathrm{SD}=3.61)$.

The results of descriptive statistics the Hypothesis showing that SFAS-accounting hedgers increased the level of accounting hedges and did not use any economic hedges, while SFAS133-compliant hedgers increased the level of accounting hedges and decreased the level of economic hedges. This is an indication that SFAS-accounting hedgers hedge in a limited fashion only where hedge accounting treatment is attained thus evading additional earnings volatility and decreasing just a limited amount of economic risks, while SFAS133-compliant hedgers hedge in a more optimal economic way thus recognizing the volatility in earnings originated from those hedges that do not qualify for hedge accounting. 
Table 1. Descriptive Stats: Notional Value of Hedging Instruments for SFAS133 Ahs \& CHs

\begin{tabular}{|c|c|c|c|c|c|c|c|}
\hline \multicolumn{4}{|c|}{$\begin{array}{c}\text { SFAS } 133 \\
\text { ACCCOUNTING HEDGERS }\end{array}$} & \multirow[b]{2}{*}{$\begin{array}{l}\text { ACCOUNTING } \\
\text { HEDGES* }\end{array}$} & \multicolumn{3}{|c|}{$\begin{array}{c}\text { SFAS } 133 \\
\text { COMPLIANT HEDGERS }\end{array}$} \\
\hline ACCOU & HEDGES* & $\begin{array}{l}\text { CASH FLOW } \\
\text { HEDGES }\end{array}$ & $\begin{array}{l}\text { FAIR VALUE } \\
\text { HEDGES }\end{array}$ & & $\begin{array}{l}\text { CASH } \\
\text { FLOW }\end{array}$ & $\begin{array}{c}\text { FAIR } \\
\text { VALUE }\end{array}$ & $\begin{array}{l}\text { ECONOMIC } \\
\text { HEDGES }\end{array}$ \\
\hline \multicolumn{8}{|c|}{2009 NOTIONAL VALUE } \\
\hline $\mathrm{N}$ & 4 & 23 & 22 & 6 & 16 & 13 & 24 \\
\hline M & 2.960 & 1.054 & 0.733 & 1.898 & 1.413 & 0.971 & 1.790 \\
\hline SD & 3.344 & 2.462 & 1.880 & 4.264 & 2.423 & 1.887 & 3.450 \\
\hline Min & 4.057 & 0.037 & 0.019 & 0.002 & 0.000 & 0.005 & 0.001 \\
\hline Max & 7.873 & 95.00 & 79.807 & 10.60 & 6.672 & 5.926 & 1.484 \\
\hline SEM & 1.672 & 5.134 & 4.009 & 1.774 & 0.605 & 0.523 & 0.070 \\
\hline Q1 & 1.262 & 0.195 & 0.269 & 0.080 & 0.015 & 0.013 & 0.012 \\
\hline Mdn & 1.781 & 0.550 & 0.501 & 0.216 & 0.187 & 0.017 & 0.050 \\
\hline Q3 & 3.479 & 5.101 & 2.080 & 0.293 & 1.175 & 0.632 & 0.102 \\
\hline \multicolumn{8}{|c|}{2008 NOTIONAL VALUE } \\
\hline $\mathrm{N}$ & 4 & 27 & 21 & 6 & 15 & 12 & 24 \\
\hline $\mathrm{M}$ & 2.205 & 0.260 & 0.122 & 1.031 & 1.680 & 0.946 & 1.950 \\
\hline SD & 4.407 & 2.680 & 1.790 & 2.337 & 2.380 & 1.261 & 3.610 \\
\hline Min & 5.011 & 0.001 & 0.0025 & 0.023 & 0.001 & 0.244 & 0.001 \\
\hline Max & 8.817 & 0.850 & 0.550 & 5.800 & 0.669 & 4.743 & 1.530 \\
\hline SEM & 2203 & 0.051 & 0.039 & 0.954 & 0.061 & 0.364 & 0.073 \\
\hline Q1 & 0.016 & 0.049 & 0.014 & 0.034 & 0.006 & 0.407 & 0.010 \\
\hline Mdn & 0.023 & 0.157 & 0.019 & 0.052 & 0.012 & 0.626 & 0.038 \\
\hline Q3 & 2.206 & 0.344 & 0.275 & 0.186 & 0.273 & 0.929 & 0.151 \\
\hline
\end{tabular}

* Accounting Hedges include both the Notional Value of Cash Flow and Fair Value Hedges

Table 2. Two-Sample t-test: 2009 Difference in Notional between CHs \& AHs

\begin{tabular}{cccc}
\hline 2009 & $\mathrm{~N}$ & $\mathrm{M}$ & $\mathrm{SD}$ \\
\hline SFAS133 Accounting Hedgers (AH) & 38 & 1.37 & 2.56 \\
SFAS133 Compliant Hedgers $\quad(\mathrm{CH})$ & 24 & 0.21 & 0.38 \\
difference (AH2009-CH2008) $=1.16$ & & \\
standard error of difference $=0.52$ & & \\
$t$ test of difference $=\mathrm{H} 0: \mu 1-\mu 2=0: \mathrm{t}=2.20, \quad p=.0316, d f=60$ & & \\
\hline
\end{tabular}

\subsection{Paired t Tests}

To investigate whether or not BHCs exhibited a more accounting responsive corporate risk management approach after the 2008 amendment of SFAS 133, a paired sample t test was conducted to compare the total notional value of derivative instruments of SFAS133-compliant hedgers and SFAS133-accounting hedgers. Table 2 provides the $t$ test results of the differences between the total notional value of cash flow hedges, fair value hedges, and economic hedges of the two groups of BHCs in 2009, one year after the amendment of SFAS 133. The $t$ test revealed that there was a statistically significant difference between the mean notional values of derivative instruments of the two BHC groups, $\mathrm{t}(60)=-2.20, \mathrm{p} \leq .05$ (two-tailed test). The mean notional value of derivative instruments of "SFAS133- Accounting Hedgers" $(\mathrm{M}=1.37, \mathrm{SD}=2.56)$ was higher than the mean notional value of derivatives of "SFAS133-Compliant Hedgers" $(\mathrm{M}=0.21, \mathrm{SD}=0.38)$.

Table 3 provides the $t$ test results of the differences between the total notional value of cash flow hedges, fair value hedges, and economic hedges of the two groups of BHCs in 2008, the year SFAS 133 was amended. The $t$ test revealed that there was not a statistically significant difference between the mean notional values of derivative instruments of SFAS133 accounting hedgers $(\mathrm{M}=2.57$, $\mathrm{SD}=14.26)$ and SFAS133 compliant hedgers $(\mathrm{M}=0.56$, $\mathrm{SD}=1.48$ ), conditions; $\mathrm{t}(60)=-2.20, \mathrm{p} \geq .05$ (two-tailed test), in 2008 the year SFAS 133 was amended. 
Table 3. Two-Sample t-test: 2008 Difference in Notional between CHs \& AHs

\begin{tabular}{|c|c|c|c|}
\hline 2008 & $\mathrm{~N}$ & M & SD \\
\hline SFAS133 Accounting Hedgers (AH) & 38 & 2.57 & 4.26 \\
\hline SFAS133 Compliant Hedgers $\quad(\mathrm{CH})$ & 24 & 0.56 & 1.48 \\
\hline \multicolumn{4}{|l|}{ difference $(\mathrm{AH} 2009-\mathrm{CH} 2008)=2.01$} \\
\hline \multicolumn{4}{|l|}{ standard error of difference $=2.93$} \\
\hline \multicolumn{4}{|l|}{$t$ test of difference $=\mathrm{H}_{0}: \mu 1-\mu_{2}=0: \mathrm{t}=0.69, \quad p=.4953, d f=60$} \\
\hline 2008 & $\mathrm{~N}$ & M & SD \\
\hline SFAS133 Compliant Hedgers (CH) 2009 & 24 & 0.17 & 0.34 \\
\hline SFAS133 Compliant Hedgers (CH) 2008 & 24 & 0.19 & 0.36 \\
\hline \multirow{2}{*}{\multicolumn{4}{|c|}{$\begin{array}{c}\text { difference }(\mathrm{CH} 2009-\mathrm{CH} 2008)=-0.016 \\
\text { standard error of difference }=0.10\end{array}$}} \\
\hline & & & \\
\hline$t$ test of difference $=\mathrm{H}_{0}: \mu 1-\mu_{2}=0: \mathrm{t}=-0.16$, & $p=.4379$ & $d f=60$ & \\
\hline
\end{tabular}

Table 4 provides the $t$ test results of the difference between the 2009/2008 notional values of economic hedges of SFAS 133 compliant hedgers. The $t$ test revealed that there was not a statistically significant difference between the 2009 mean notional values of economic hedges $(\mathrm{M}=0.17$, $\mathrm{SD}=0.34$ ) and the 2008 mean notional values of economic hedges $(\mathrm{M}=0.19, \mathrm{SD}=0.36)$ of SFAS133 compliant hedgers, conditions; $\mathrm{t}(60)=-0.16, \mathrm{p} \geq .05$ (one-tailed, lower).

The results suggest that SFAS133-accounting hedgers exhibited a more accounting responsive corporate risk management approach in 2009 after the 2008 amendment of SFAS 133. SFAS133- accounting hedgers, along with the reevaluation of their risk management approach captured the benefits of hedge accounting and effectively addressed the implementation of SFAS 133 since it requires early methodical planning to determine the evaluation of hedge effectiveness according to Coughlin[10] in an attempt to manage any associated earnings volatility. SFAS133compliant hedgers, on the other side, did not exhibit an accounting responsive corporate risk management approach in 2009 after the 2008 amendment of SFAS 133, and continued hedging in an optimal economic way (thus recognizing the volatility in earnings originated from those hedges that did not qualify for hedge accounting but decreasing economic risks).

\subsection{Multiple Regression Analysis}

Multiple regression model $\# 1$ were used to test if the corporate risk management variables significantly predicted a corporate risk management approach that is more accounting responsive for SFAS133-accounting hedgers, while it is more optimal in an economic way for SFAS133-compliant hedgers one year after the 2008 amendment of SFAS133. Table 5 presents the multiple regression results of the Hypothesis. To test the effects of
SFAS 133 on BHCs corporate risk management approach the total notional value of all derivative instruments designated as cash flow hedges, fair value hedges and economic hedges (NOTIONAL) for both groups of BHCs, were regressed against the following predictor variables: EVol, ESmooth, ESmooth1, FINLEV, INFOASY, UNDERC, MNGRisk, CapAdeq1, IRLIBOR, HEDGEIN cash flow, and HEDGEIN fair value and, NETGains/Losses (only for SFAS 133-compliant hedgers). The results of the regression indicated that the combination of the variables explained $68.9 \%$ of the variance in NOTIONAL for SFAS133-accounting hedgers $(\mathrm{R} 2=.689, \mathrm{~F}(11,26)=5.24$, $\mathrm{p}<.005$ ), while they explained $86.1 \%$ of the variance in NOTIONAL for SFAS133-compliant hedgers $(\mathrm{R} 2=.861, \mathrm{~F}$ $(13,10)=4.78, \mathrm{p}<.005)$.

SFAS133-Accounting Hedgers. Multiple regression analysis were used to test if the corporate-risk management hedging variables significantly predicted a more accounting responsive corporate risk management approach for SFAS133-accounting hedgers one year after the 2008 amendment of SFAS133. The variables produced a coefficient of determination $\mathrm{R} 2$ of $.998(\mathrm{~F}(11,26)=9.90, \mathrm{p}=$ $3.57)$ for the prediction of SFAS133-accounting hedgers' corporate risk management approach (NOTIONAL). The predictor with the lowest non-significant regression coefficient ( $\mathrm{EVol}, \beta=4.8, \mathrm{t}(\mathrm{df}=26)=40.4, \mathrm{p}=5.33)$ were removed. The final regression analysis conducted had a coefficient of determination R2 of .689 $(\mathrm{F}(11,26)=5.24$, p $=.0003)$ with INFOASY $(p=.0359, \beta=1.2485, t=2.213)$ as the strongest predictor. INFOASY explained $68.9 \%$ of the variation and were positively related to SFAS133accounting hedgers' corporate risk management approach (NOTIONAL). Finally, tests for multicollinearity indicated that a very low level of multicollinearity was present for INFOASY $($ VIF $=0.1249)$. 
Table 5. Regression Analysis for Variables Predicting Notional

\begin{tabular}{|c|c|c|c|c|c|c|}
\hline \multirow[t]{2}{*}{ NOTIONAL } & \multicolumn{3}{|c|}{$\begin{array}{c}\text { SFAS-133 } \\
\text { ACCOUNTING HEDGERS } \\
\end{array}$} & \multicolumn{3}{|c|}{$\begin{array}{c}\text { SFAS-133 } \\
\text { COMPLIANT HEDGERS } \\
\end{array}$} \\
\hline & $\mathrm{B}$ & SE B & $\beta$ & $\mathrm{B}$ & SE B & $\beta$ \\
\hline \multicolumn{7}{|c|}{ Variables } \\
\hline EVol & & & & 0.1781 & 0.2848 & 0.3376 \\
\hline ESmooth & -0.016 & 0.6756 & -0.0084 & -0.060 & 0.1015 & -0.6172 \\
\hline ESmooth1 & 0.8666 & 0.1562 & 0.1113 & -0.061 & 0.4681 & 0.2858 \\
\hline FINLEV & -0.006 & 0.2911 & -1.0571 & 0.1185 & 0.2330 & 0.3072 \\
\hline INFOASY & 0.332 & 0.5642 & 0.1249 & 0.1318 & 0.1070 & -0.0002 \\
\hline UNDERC & -0.024 & 0.4177 & -0.0083 & -0.1463 & 0.7287 & -1.4274 \\
\hline MNGRisk & -0.004 & 0.2322 & -0.0056 & -0.0020 & 0.1611 & 6.1410 \\
\hline CapAdeq1 & -0.048 & 0.1647 & -0.0056 & 0.0381 & 0.3089 & -0.3786 \\
\hline IRLIBOR & 0.164 & 0.1667 & 0.0198 & -0.1225 & 0.1554 & 0.0670 \\
\hline HEDGEIN cash flow & -0.057 & 0.3911 & -1.8257 & 0.0431 & 0.3018 & -0.0072 \\
\hline HEDGEIN fair value & -0.245 & 0.4731 & -0.7712 & -0.0237 & 0.1284 & -0.0063 \\
\hline NETGains(Losses) & & & & -0.0490 & 0.3901 & -0.0388 \\
\hline OCI & -0.090 & 0.084 & -0.6488 & -0.0993 & 0.1212 & -0.1378 \\
\hline
\end{tabular}

SFAS133-Compliant Hedgers. Multiple regression analysis were used to test if the corporate-risk management hedging variables significantly predicted a less accounting responsive corporate risk management approach for SFAS133-compliant hedgers one year after the 2008 amendment of SFAS133. The variables produced a coefficient of determination R2 of .861 $(\mathrm{F}(13,10)=4.78, \mathrm{p}$ $=.009$ ) for the prediction of SFAS-compliant hedgers' corporate risk management approach (NOTIONAL), with three significant predictors of NOTIONAL -- MNGRisk, HEDGEIN cash flow, and HEDGEIN fair value. The predictors explained $86.1 \%$ of the variation in NOTIONAL for SFAS133-compliant hedgers. The strongest predictor was HEDGEIN fair value $(\mathrm{p}=.0006)$, followed by MNGRisk $(p=.0034)$, and HEDGEIN cash flow $(p=.0388)$. MNGRisk $(\beta=0.614, \mathrm{t}=3.811)$ was positively related to NOTIONAL, while HEDGEIN cash flow $(\beta=-0.0072, \mathrm{t}=$ -2.377) and HEDGEIN fair value $(\beta=-0.0063, \mathrm{t}=-4.905)$ were both negatively related to NOTIONAL. Finally, tests for multicollinearity indicated that a low level of multicollinearity were present for MNGRisk (VIF=2.050), HEDGEIN cash flow (VIF = 3.036), and HEDGEIN fair value ( $\mathrm{VIF}=2.097)$.

The multiple regression analysis results suggest that the increased level of attention corporate risk management received under SFAS 133 and the different recognition and measurement method of accounting hedges and economic hedges complicated BHCs hedging decisions and subsequently their risk management course of action. SFAS-accounting hedgers' concern of how investors will react to the possibility of increased volatility evolving from economic hedges that do not qualify for hedge accounting under SFAS 133 has driven them to adjust their corporate risk management strategy to one that is more accounting responsive to avoid analysts' negative stock valuations. SFAS-accounting hedgers' acuity that earnings volatility will be negatively deciphered by investors instigated them to give up the benefits of economic hedges in order to avoid earnings volatility at all costs. SFAS133- accounting hedgers in an attempt to manage any associated earnings volatility re-evaluated their risk management approach and captured the benefits of hedge accounting by successfully addressing the implementation of SFAS 133 since it requires early methodical planning to determine the evaluation of hedge effectiveness [10]. SFAS133-compliant hedgers, on the other side, acknowledge that it is unfeasible to engage in a hedging policy that is economically advantageous without meeting half way with the accounting impact. Compliant hedgers instigate a new exemplar for corporate risk management with the intent to find a better equilibrium between the economic risks and accounting volatility.

\section{Interpretation of Findings}

The descriptive results in Table 1 provide the 2008 and 2009 total notional value of derivative instruments designated as accounting, cash flow, fair value, and economic hedges for both groups of BHCs showing that SFAS-accounting hedgers increased the level of accounting hedges and did not use any economic hedges, while SFAS133- compliant hedgers increased the level of accounting hedges and decreased the level of economic hedges. For SFAS133-accounting hedgers the results suggest that the 2009 notional value of cash flow hedges, fair value hedges and accounting hedges is significantly higher than the 2008 notional value. For SFAS133-compliant hedgers the results suggest that the 2009 notional value of fair value 
hedges and accounting hedges is significantly higher than the 2008 notional value, while the 2009 notional value of cash flow hedges and economic hedges is significantly lower than the 2008 notional value. The descriptive results in Table 1 show that SFAS-accounting hedgers hedge in a limited fashion only where hedge accounting treatment is attained thus evading additional earnings volatility and decreasing just a limited amount of economic risks, while SFAS133-compliant hedgers hedge in a more optimal economic way thus recognizing the volatility in earnings originated from those hedges that do not comply for hedge accounting.

There is a belief in the existing accounting literature that some BHCs might have been prompted to adjust their corporate risk management strategy to one that is more accounting responsive since SFAS 133 has compromised BHCs competence to economically hedge financial and economic risks. Supported by the theoretical findings of Kolsasovsky[27], Lins et al.[28], Revsine, Collins, and Johnson[37], Peterson et al.[34], and DeMarzo et al.[12], there are concerns that the fear of increased earnings volatility derived from economic hedges that do not oblige for hedge accounting forced BHCs to decide between reducing earnings volatility in accounting terms exploiting less- competent economic risk management strategies or manage economic risks with economic hedges disregarding accounting earnings volatility.

Singh[39], Park[33], Zhang[44], and Zhou[46] found that after the implementation of SFAS 133, derivatives users had lower levels of earnings volatility and higher levels of income smoothing proposing that SFAS 133 may have driven companies' earnings management decisions. Lins et al.[28] claimed that "companies that operate in an environment where contracts are more likely to be written on accounting data" (p. 34), and award earnings volatility reduction as a risk management lead tactic will be more apprehensive to use derivatives that qualify for hedge accounting. The authors documented a considerable decline in the use of foreign- exchange and no- linear derivative instruments after the implementation of SFAS 133 for the reason that it is unlikely they will qualify for hedge accounting.

Green (2008) avowed that SFAS 133 by not allowing special hedge accounting for all relationships that may be economic hedges disinclines BHCs to use economic hedges if they feel their accounting income is going to be affected adversely, not by economic events, but by the accounting convention applied to a hedge. Eckstein, Markelevich, and Reinstein[13] substantiated the correspondence of fair-value hedges with deferred debits/assets and cash-flow hedges with deferred credits/revenue imposing that the new guidance in SFAS 133 could encourage BHCs to manipulate earnings management and objectively defer the recognition of their hedging activities in the financial statements.

The results of paired $t$ tests in Table 2 support Hypothesis I illustrating that there is a statistically significant difference in the mean notional value of derivative hedging instruments for SFAS-accounting hedgers and SFAS133-compliant hedgers in 2009 one year after the 2008 amendment of SFAS 133. The results of paired t tests in Table 3 show that there is not a statistically significant difference in the mean notional value of derivative instruments for SFAS133 accounting hedgers and SFAS133 compliant hedgers in 2008 the year SFAS 133 was amended. The $\mathrm{t}$ test results in Table $\mathbf{4}$ reveal that for SFAS133-compliant hedgers there is not a statistically significant difference between the 2009 means notional values of economic hedges and the 2008 mean notional values of economic.

The mean notional value of derivatives designated as hedging instruments for 2009 is 1.37 for SFAS133accounting hedgers and 0.21 for SFAS133- compliant hedgers. The mean notional value of derivatives designated as hedging instruments for 2008 is 0.25 for SFAS133accounting hedgers and 0.56 for SFAS133- compliant hedgers. In 2009 the mean notional value of hedges for SFAS133- accounting hedgers exceeds that of SFAS133compliant hedgers by $65 \%$, while the mean notional value of hedges for SFAS133- accounting hedgers is $55 \%$ higher in 2009. From the entire population of Peer Group 1 and Peer Group 2, SFAS133-accounting hedgers represent $61 \%$ of the BHCs that use only derivatives instruments designated as accounting hedges and SFAS133-compliant hedgers represent $38 \%$ of the BHCs that use derivatives instruments designated as economic hedges.

The results suggest that SFAS133- accounting hedgers exhibited a more accounting responsive corporate risk management approach than the SFAS133- compliant hedgers in 2009 one year after the 2008 amendment of SFAS 133. This study evokes that hedge accounting under SFAS 133 do actually affect the hedging behavior of SFAS133accounting hedgers and SFAS133- compliant hedgers in different ways. SFAS133- accounting hedgers in an attempt to manage any associated earnings volatility re- evaluated their risk management approach and captured the benefits of hedge accounting by successfully addressing the implementation of SFAS 133 since it requires early methodical planning to determine the evaluation of hedge effectiveness (Coughlin, 2003).

The hedge accounting rules of SFAS 133 advocate an opportunistic earnings management behavior. BHCs along with the reassessment of their corporate risk management strategy have to deal with the implementation of SFAS 133 since the standard "places the burden on management to design appropriate effectiveness tests, and measure the change in fair value or cash flows attributable to the risk being hedged" [14, p.129]. The results are consistent with the empirical accounting studies of Singh[39]; Park[33]; Zhang[44];and Zhou[46] who found that derivatives users after the implementation of SFAS 133 had lower levels of earnings volatility and higher levels of income smoothing proposing that SFAS 133 determine the earnings management decisions of companies.

Furthermore, the results of this study are in accordance to 
the results of Hughen[23] and Glaum and Klocker[18]. Hughen[23] found that "firms' ability to meet earnings is positively associated with managers focusing more on accounting earnings than on economic earnings" (p. 1052) concluding that managers will maintain an economic hedge if they consider that the economic risk exposure is imperative compared to the volatility in earnings. Glaum et al.[18] presumed that firms with higher leverage and revenue- orientated hedging policies are more inclined to revise their corporate risk management practice to safeguard the implementation of hedge accounting accepting an elevated economic risk exposure than larger firms with regularly derivative usage and higher growth opportunities.

The multiple regression analysis shows that the most significant determinant of hedging for SFAS-accounting hedgers is information asymmetry which is computed as the logarithm of the number of financial analysts assessing the performance of a BHC annually and for SFAS133-compliant hedgers is hedge ineffectiveness which measures BHCs ineffective portion of the amount of gain (loss) recognized in income on derivatives designated as cash flow or fair value hedges. The results suggest that the increased level of attention corporate risk management received under SFAS 133 and the different recognition and measurement method of accounting hedges and economic hedges convoluted BHCs hedging decisions and subsequently their risk management course of action. SFAS-accounting hedgers' concern of how investors will react to the possibility of increased volatility evolving from economic hedges that do not comply for hedge accounting under SFAS 133 has driven them to adjust their corporate risk management strategy to one that is more accounting responsive to avoid analysts' negative stock valuations. SFAS-accounting hedgers' acuity that earnings volatility will be negatively deciphered by investors instigated them to give up the benefits of economic hedges in order to avoid earnings volatility at all costs. SFAS133-compliant hedgers, on the other side, acknowledge that it is unfeasible to engage in a hedging policy that is economically advantageous without meeting half way with the accounting impact. Compliant hedgers instigate a new exemplar for corporate risk management with the intent to find a better equilibrium between the economic risks and accounting volatility.

\section{Conclusions}

This study examined the derivatives and hedging activities under SFAS 133 of the entire population of the Peer 1 and Peer 2 BHCs of the Federal Reserve System. From the entire target population of $167 \mathrm{BHCs}$ only 62 banks use derivatives that qualify for hedge accounting from which $38 \mathrm{BHCs}$ are classified as SFAS133-accounting hedgers and 24 BHCs are classified as SFAS133-compliant hedgers. The limited number of derivative users confirms that hedge accounting is very expensive for small banks to implement and maintain since they do not have the enormous resources needed to dedicate to training their personnel in derivatives, hedge accounting, and hedge effectiveness testing according to Pollock[35]. Whalen[11] argued that "the Fed's effort to make the world safe for derivatives, fails from the incompetence of small banks to understand and execute derivatives triggering major difficulties in the U.S. financial system" as cited in Christen[11, p.11].

Norris[31] argued that although hedge accounting under SFAS 133 made it possible for companies to smooth their financial statements by preventing earnings from "the gyrations in value" of certain derivative hedging instruments. Hedge effectiveness has asserted many challenges for many corporations according to Hughen[23] and hedge accounting has been criticized for its complexity derived from the fact that not all hedges qualify for hedge accounting. According to the extant accounting literature, economic hedges that do not comply for hedge-accounting, while reducing market risk exposure and earnings volatility in economic terms, increase earnings volatility in accounting terms since SFAS 133 obliges all fair-value variations of derivative instruments with no-accounting hedging designation to be recognized in income. Consequently, executives are obligated to use only accounting hedges concentrating on accounting earnings regardless of the economic risk exposure or use economic hedges concentrating on economic earnings regardless of the associated earnings volatility based on Hughen[23]; Kolbasovsky[27]; Revsine et al.[37].

SFAS-accounting hedgers' concern of how investors will react to the possibility of increased volatility evolving from economic hedges that do not comply for hedge accounting under SFAS 133 has driven them to adjust their corporate risk management strategy to one that is more accounting responsive to avoid analysts' negative stock valuations. SFAS-accounting hedgers' acuity that earnings volatility will be negatively deciphered by investors instigated them to give up the benefits of economic hedges in order to avoid earnings volatility at all costs. SFAS133-compliant hedgers, on the other side, acknowledge that it is unfeasible to engage in a hedging policy that is economically advantageous without meeting half way with the accounting impact. Compliant hedgers instigate a new exemplar for corporate risk management with the intent to find a better equilibrium between the economic risks and accounting volatility.

This study extended prior research on corporate risk management activities of BHCs and may effect social change by presenting new evidence on the effects of SFAS 133 economic hedges on earnings volatility. This research may influence society positively by finding new evidence of the degree and causes of BHCs' earnings volatility and providing the empirical support for the FASB and the SEC to improve the qualitative disclosures of SFAS 133 and increase the transparency and visibility of accounting hedges and economic hedges in the financial statements. 


\section{Appendix A}

Variable Definition and Measurement

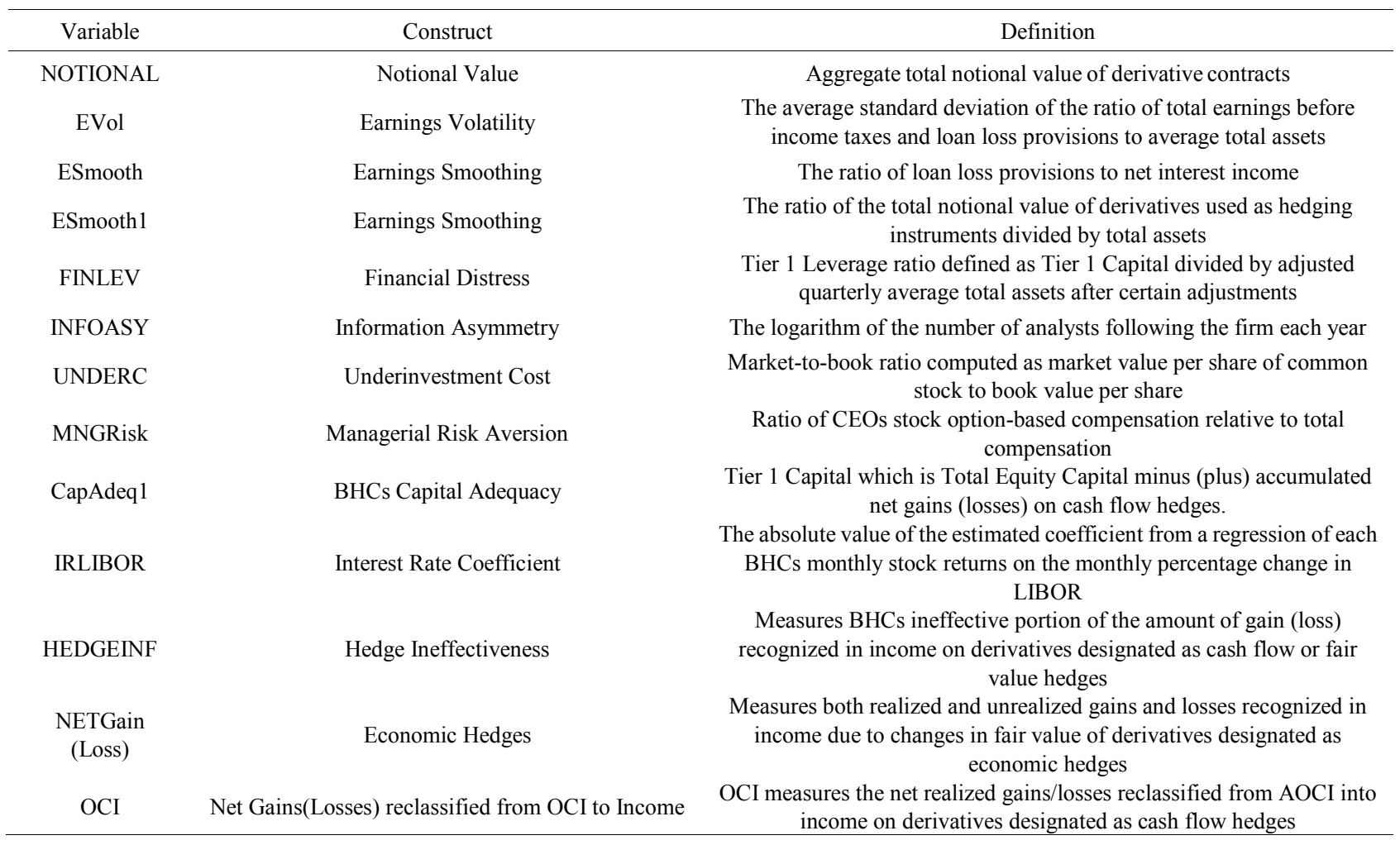

\section{Appendix B}

SFAS 133 Classification of BHCs

\begin{tabular}{|c|c|c|c|}
\hline INSTITUTION NAME & $\begin{array}{c}\text { SFAS } 133 \\
\text { COMPLIANT } \\
\text { HEDGERS }\end{array}$ & INSTITUTION NAME & $\begin{array}{c}\text { SFAS } 133 \\
\text { ACCOUNTING } \\
\text { HEDGERS } \\
\end{array}$ \\
\hline BANK OF AMERICA CORP & SFAS133 CH & JPMORGAN CHASE \& CO & SFAS133 AH \\
\hline CITIGROUP INC & SFAS133 CH & MORGAN STANLEY & SFAS133 AH \\
\hline WELLS FARGO \& COMPANY & SFAS133 CH & HSBC NORTH AMERICA HOLDING INC & SFAS133 AH \\
\hline METLIFE, INC & SFAS133 CH & BANK OF NEW YORK MELLON CORP & SFAS133 AH \\
\hline $\begin{array}{l}\text { PNC FINANCIAL SERVICES GROUP, } \\
\text { INC }\end{array}$ & SFAS133 CH & STATE STREET CORPORATION & SFAS133 AH \\
\hline US BANCORP & SFAS133 CH & TD BANK US HOLDING COMPANY & SFAS133 AH \\
\hline SUNTRUST BANKS, INC & SFAS133 CH & KEYCORP & SFAS133 AH \\
\hline CAPITAL ONE FINANCIAL CORP & SFAS133 CH & NORTHERN TRUST CORPORATION & SFAS133 AH \\
\hline BB\&T CORPORATION & SFAS133 CH & M\&T BANK CORPORATION & SFAS133 AH \\
\hline REGIONS FINANCIAL CORP & SFAS133 CH & MARSHALL \& ILSLEY CORPORATION & SFAS133 AH \\
\hline AMERICAN EXPRESS COMPANY & SFAS133 CH & ZIONS BANCORPORATION & SFAS133 AH \\
\hline FIFTH THIRD BANCORP & SFAS133 CH & HUNTINGTON BANCSHARES, INC & SFAS133 AH \\
\hline CIT GROUP INC & SFAS133 CH & SYNOVUS FINANCIAL CORP. & SFAS133 AH \\
\hline COMERICA INCORPORATED & SFAS133 CH & FIRST CITIZENS BANCSHARES, INC & SFAS133 AH \\
\hline DISCOVER FINANCIAL SERVICES & SFAS133 CH & CITY NATIONAL CORPORATION & SFAS133 AH \\
\hline BANCO POPULAR,INC & SFAS133 CH & COMMERCE BANCSHARES, INC & SFAS133 AH \\
\hline FIRST HORIZON NATIONAL CORP. & SFAS133 CH & WEBSTER FINANCIAL CORPORATION & SFAS133 AH \\
\hline BOK FINANCIAL CORPORATION & SFAS133 CH & CULLEN/FROST BANKERS, INC & SFAS133 AH \\
\hline
\end{tabular}




\begin{tabular}{|c|c|c|c|}
\hline ASSOCIATED BANC-CORP & SFAS133 CH & VALLEY NATIONAL BANCORP & SFAS133 AH \\
\hline FIRST NIAGARA GROUP, INC & SFAS133 CH & MB FINANCIAL, INC & SFAS133 AH \\
\hline WINTRUST FINANCIAL CORP. & SFAS133 CH & SUSQUEHANNA BANCSHARES, INC & SFAS133 AH \\
\hline OLD NATIONAL BANCORP & SFAS133 CH & SVB FINANCIAL GROUP & SFAS133 AH \\
\hline SUN BANCORP, INC & SFAS133 CH & CITIZENS REPUBLIC BANCORP, INC & SFAS133 AH \\
\hline \multirow[t]{15}{*}{ UNITED BANKSHARES, INC } & SFAS133 CH & FIRST MERIT CORPORATION & SFAS133 AH \\
\hline & & FIRST FINANCIAL BANCORP & SFAS133 AH \\
\hline & & FIRST MERCHANTS CORPORATION & SFAS133 AH \\
\hline & & FIRST MIDWEST BANCORP, INC & SFAS133 AH \\
\hline & & IBERIA BANK CORPORATION & SFAS133 AH \\
\hline & & INDEPENDENT BANK CORP & SFAS133 AH \\
\hline & & NATIONAL PENN BANCSHARES, INC & SFAS133 AH \\
\hline & & PLAINSCAPITAL CORPORATION & SFAS133 AH \\
\hline & & SCOTIABANK & SFAS133 AH \\
\hline & & RENASANT & SFAS133 AH \\
\hline & & SIMMONS FIRST NATIONAL CORP & SFAS133 AH \\
\hline & & STERLING BANCSHARES, INC & SFAS133 AH \\
\hline & & TAYLOR CAPITAL GROUP, INC & SFAS133 AH \\
\hline & & TRUSTMARK CORPORATION & SFAS133 AH \\
\hline & & UNITED COMMUNITY BANK, INC & SFAS133 AH \\
\hline
\end{tabular}

\section{REFERENCES}

[1] Banking Circular 277. (1993). Risk management of financial derivatives. Retrieved from http://www.occ.treas.gov/handbook/deriv.pdf

[2] Bartram,M. S., Brown,W. G., \& Conrad, J. (2007). SSRN Working Paper Series, 52. Retrieved from http://papers.ssrn.com/sol3/papers.cfm?abstract_id=1210422

[3] Comptroller of the Currency, Administrator of National Banks (OCC). 2009. OCC's quarterly report on bank trading and derivatives activities: Third quarter 2009. U.S. Department of the Treasury, Washington, DC. Retrieved January 4, 2010, from

http://www.occ.treas.gov/ftp/release/2009-161a.pdf

[4] Coughlan, G. (2003). Heat: A framework for evaluating hedge effectiveness. Journal of derivatives accounting, 1(2), 1-4. doi:10.1142/S0219868104000178

[5] Christner, R., (2006). The problem with derivatives in valuing securities. International Business \& Economics Research Journal, 5(11), 9-18. Retrieved from http://journals.cluteonline.com/index.php/IBER

[6] DeMarzo, P., \& Duffie, D. (1995). Corporate incentives for hedging and hedge accounting. The Review of Financial Studies, 8, 743-771. doi:10.1093/rfs/8.3.743

[7] Eckstein, C., Markelevich, A., \& Reinstein, A. (2008). Accounting for derivative instruments and hedging activities (SFAS No. 133). Review of Accounting and Finance, 7(2), 131-149. doi:10.1108/14757700810874119

[8] FASB News Release. (09/12/2008). FASB Staff Position
(FSP) No. 133-1 and FIN 45-4, Disclosures about credit derivatives and certain guarantees: An amendment of FASB Statement No. 133 and FASB Interpretation No. 45. FASB: Norwalk, CT. Retrieved on February 8, 2010 from http://www.fasb.org/news/nr091208.shtml

[9] Gilkeson, H. J., \& Smith, D. S. (2006). The impact of derivatives on commercial banks (2000-2004). University of Central Florida Working Paper. Retrieved from http://www.bus.ucf.edu/gilkeson/documents/Research/GS06 d7.13.06.pdf

[10] Glaum, M., \& Klöcker, A. (2011). Hedge accounting and its influence on financial hedging: when the tail wags the dog. Accounting \& Business Research (Taylor \& Francis), 41(5), 459-489. doi:10.1080/00014788.2011.573746

[11] Green, F., J. (2008). Accounting for derivatives and hedging. Chicago, IL: CCH.

[12] Guay, W., \& Kothari, P. S. (2003). How much do firms hedge with derivatives? Journal of Financial Economics, 70, 423-461. doi:10.1016/S0304-405X(03)00179-X

[13] Hirtle, J. B. (1997). Derivatives, portfolio composition, and bank holding company interest rate risk exposure. Journal of Financial Services Research, 12(2-3), 243- 266. doi:10.1023/A:1007930904536

[14] Hodder, D. L., Hopkins, E. P., \& Wahlem, M. J. (2006). Risk-relevance of fair-value income measures for commercial banks. Accounting Review, 81(2), 337-375. doi:10.2308/accr.2006.81.2.337

[15] Hughen, L. (2010). When do accounting earnings matter more than economic earnings? Evidence from hedge accounting restatements. Journal of Business Finance \& Accounting, 37(9/10), 1027-1056. doi:10.1111/j.1468-5957. 2010.02216.x 
[16] Hutchison, D., (n.d.).Economics, Accounting Practices, and Earnings Volatility in Mortgage Banking. Retrieved from $\mathrm{http}: / / w w w . r e s e a r c h g a t e . n e t / p u b l i c a t i o n / 237571920$ Econo mics_Accounting_Practices_and_Earnings_Volatility_in_M ortgage_Banking

[17] Kolbasovsky, L. (2009). The trade-off between risk management and earnings volatility: Evidence from restatements (doctoral )., Retrieved from Dissertations \& Theses: Full Text. (Publication No. AAT 3383915).

[18] Lins, K., Servaes, H., \& Tamayo, A. (2009). Does fair value reporting affect risk management? International survey evidence. SSRN Working Paper Series, 56. Retrieved December 10, 2009, from Accounting \& Tax Periodicals. (Document ID: 1780999751).

[19] McCormack, J. (2005). Morgan Stanley roundtable on enterprise risk management and corporate strategy. Journal of Applied Corporate Finance, 17(3), 33-61. Received from http://www.morganstanley.com/web/jacfjournal/cgi-bin/jour nal.cgi

[20] Norris, F., (2005). Smooth earnings growth was reassuring, but it was often fictional. Retrieved from the New York Times website: http://www.nytimes.com/2005/05/06/business/06norris.html

[21] Office of the Comptroller of the Currency. (2005). Interagency advisory on accounting and reporting for commitments to originate and sell mortgage loans. Retrieved on January 10, 2010 from http://www.federalreserve.gov/boarddocs/srletters/2005/SR0 510a1.pdf

[22] Park, J. (2005). The economic consequences of FAS-133 for bank holding companies. Bank Accounting and Finance, 18(6), 19-26. Retrieved from http://www.inderscience.com/jhome.php?jcode=ijbaaf

[23] Peterson, M., \& Thiagarajon, S. R. (2000). Risk measurement and hedging: With and without derivatives. Financial
Management, 29(4), 5-29. doi:10.2307/3666367

[24] Pollock, A. J. (2005). American Housing GSEs; Past Triumpshs, Present Tensions, Possible Futures. Housing Finance International, 19(3), 41-46.

[25] Revsine, L., Collins, W. C., \& Johnson, W. B. (2002). Financial reporting \& analysis (2nd ed.). Upper Saddle River, NJ: Prentice Hall.

[26] Singh, A. (2008). The determinants of the decision to use financial derivatives in the lodging industry. Journal of Hospitality \& Tourism Research, 32(4), 423-447. doi:10.1177/1096348008321364

[27] Thapa, S., \& Brown, C.L. (2005). The impact of FAS 133: Accounting for derivatives and hedging on financial institution returns. Journal of Commercial Banking and Finance, 4(2), 91-97. Retrieved from http://www.alliedacademies.org/

[28] Tromblem, A. M. (2003). Accounting for derivatives and hedging. New York, NY: McGraw-Hill.

[29] Wang, X. (2005). Stock return dynamics under earnings management. Yale ICF Working Paper No. 06-01, 41. Retrieved from http://papers.ssrn.com/sol3/papers.cfm?abstract_id=870924

[30] Zhang, H. (2009). Effect of derivative accounting rules on corporate risk management behavior. Journal of Accounting \& Economics, 47(3), 244-264. doi:10.1016/j.jacceco.2008.1 1.007

[31] Zhao, F., \& Moser, J. (2009). Use of derivatives and bank holding company interest rate risk. Banking \& Finance Review, 1(1), 51-62. Retrieved from http://www.bankingandfinancereview.com/bfr/index.php/bfr

[32] Zhou, H. (2009). Does fair value accounting for derivatives improve earnings quality? SSRN Working Paper Series, 25. Retrieved December 10, 2009, from Accounting \& Tax Periodicals. (Document ID: 1871162091). 